\title{
In vitro effects of sitosterol and sitostanol on mitochondrial respiration in human brown adipocytes, myotubes and hepatocytes
}

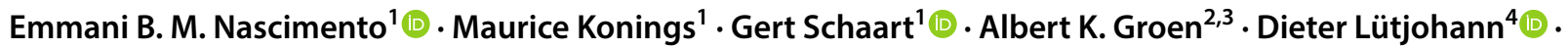

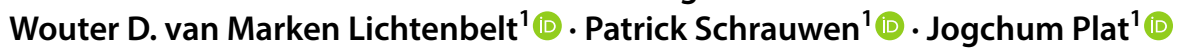

Received: 11 January 2019 / Accepted: 8 July 2019 / Published online: 17 July 2019

(c) The Author(s) 2019

\begin{abstract}
Purpose Lowering of LDL cholesterol levels by plant sterols and stanols is associated with decreased risk of cardiovascular disease in humans. Plant sterols and stanols also lower triacylglycerol (TG). However, it is not fully understood how reduction in TG is achieved and what the full potential of plant sterols and stanols is on whole-body metabolism. We here hypothesize that high levels of plant sterols and stanols stimulate whole-body energy expenditure, which can be attributed to changes in mitochondrial function of brown adipose tissue (BAT), skeletal muscle and liver.

Methods Phytosterolemic mice were fed chow diets for 32 weeks to examine whole-body weight gain. In vitro, 24-h incubation were performed in adipocytes derived from human BAT, human myotubes or HepG2 human hepatocytes using sitosterol or sitostanol. Following mitochondrial function was assessed using seahorse bioanalyzer.

Results Chow feeding in phytosterolemic mice resulted in diminished increase in body weight compared to control mice. In vitro, sitosterol or sitostanol did not change mitochondrial function in adipocytes derived from human BAT or in cultured human myotubes. Interestingly, maximal mitochondrial function in HepG2 human hepatocytes was decreased following sitosterol or sitostanol incubation, however, only when mitochondrial function was assessed in low glucose-containing medium. Conclusions Beneficial in vivo effects of plant sterols and stanols on lipid and lipoprotein metabolism are well recognized. Our results indicate that alterations in human mitochondrial function are apparently not involved to explain these beneficial effects.
\end{abstract}

Keywords Cellular respiration $\cdot$ Sitosterol $\cdot$ Sitostanol $\cdot$ Brown adipose tissue $\cdot$ Mitochondria

Jogchum Plat

j.plat@maastrichtuniversity.nl

1 Department of Nutrition and Movement Sciences, NUTRIM School of Nutrition and Translational Research in Metabolism, Maastricht University, Maastricht $6200 \mathrm{MD}$, The Netherlands

2 Department of Vascular Medicine, Amsterdam Diabetes Center, Amsterdam University Medical Center, Amsterdam 1105 AZ, The Netherlands

3 Department of Pediatrics, University of Groningen, University Medical Center Groningen, Groningen 9713 ZG, The Netherlands

4 Institute of Clinical Chemistry and Clinical Pharmacology, University Hospital , 53127 Bonn, Germany

\section{Introduction}

Dietary plant sterols or stanols lower intestinal cholesterol absorption, which results in lower serum LDL cholesterol. A daily intake of 2-g plant sterols and/or plant stanols lowers serum LDL cholesterol up to 10\% [1]. LDL cholesterol is a causal risk factor for the development of cardiovascular disease, thus lowering serum LDL cholesterol would reduce the risk to develop cardiovascular disease. Besides lowering serum LDL cholesterol, plant sterols and plant stanols lower serum triacylglycerol (TG) levels, especially in subjects with elevated serum TG who are at risk to develop metabolic disease [2].

Although the evidence that fasting TGs are independent risk factors for cardiovascular disease is weak [3], accumulating evidence suggests that postprandial TGs are independent risk factors $[4,5]$. So far, several studies have demonstrated TG-lowering effects of plant sterols and stanols [6, 
7],however, the mechanism behind the TG-lowering effects of plants sterols and stanols remains unclear. In C57B1/6 mice on a high-fat diet (HFD), both plant sterols and stanols lowered hepatic VLDL production [8], however, the molecular explanation for this effect remains so far unknown. Furthermore, we have demonstrated in humans that plant stanol consumption strongly reduced serum concentration of large TG-rich VLDL in subjects with the metabolic syndrome [9]. Besides reduced hepatic VLDL-1 production, the reduced concentration of VLDL-1 particles could also be explained through enhanced TG clearance from the circulation. Previously, we indirectly excluded a role for LPL-mediated TG uptake in white adipose tissue (WAT) and muscle. No change was observed in circulating concentrations of apoC2 and apoC 3 during the postprandial phase, the activator, and inhibitor of LPL, respectively [10]. However, recent evidence suggests that - at least in mice- a considerable fraction of circulating TGs is cleared from the circulation by brown adipose tissue (BAT). BAT, as opposed to white adipose tissue (WAT), is able to combust lipids and glucose as fuel resulting in heat production [11]. Uncoupling protein 1 (UCP1) present in the mitochondria of brown adipocytes, uncouples the proton gradient in the electron transport chain generating heat instead of ATP. Because of this hallmark, BAT has been coined an important target to combat metabolic disease $[12,13]$. With respect to lipid metabolism, BAT stimulation via cold exposure in humans specifically showed uptake of the FFA tracer ${ }^{18}$ F-FTHA which was not observed in WAT or muscle [14]. Cold-exposed mice subjected to an oral lipid tolerance test, did not show changes in TG concentrations due to active BAT [15]. Also pharmacological intervention with metformin in mice, lowered circulating levels of TGs via increased VLDL-TG clearance by BAT [16]. Activated BAT might be an important player in lipid metabolism, however, it remains unexplored whether BAT plays a role in the action of plant sterols and stanols. Also the involvement of other organs with high mitochondrial density should not be overlooked. Therefore, we here examined how increasing plant sterols and stanols in mice affected whole-body metabolism in mice. Furthermore, we investigated if the TG-lowering action of plant sterols and plant stanols could be attributed to mitochondrial activity in BAT, skeletal muscle or liver.

\section{Materials and methods}

\section{Materials}

Stock solutions of sitosterol and sitostanol (Sigma) were prepared in ethanol and provided to the different in vitro cell models. Final sitosterol and sitostanol concentrations used were $12 \mu \mathrm{M}$ and $1.2 \mu \mathrm{M}$, respectively, and compared to ethanol as carrier control. All conditions were set at identical ethanol concentration of $0.25 \%$.

\section{Animal experiments}

Male age-matched ApoE $\times$ ABCG8 knockout mice and ApoE knockout mice (C57B1/6J background, in house breeding), were housed in a light (12:12)- and temperaturecontrolled $\left(21^{\circ} \mathrm{C}\right)$ facility and received laboratory chow (RMH-B, Hope Farms, Woerden, The Netherlands) ad libitum. ApoE $\times$ ABCG8 knockout (KO) mice and apoE KO mice were fed chow diet for 32 weeks. Body weight development was monitored by measuring body weight of the mice at weeks 16, 24, 28, and 32. Experiments were conducted in conformity with the law on the welfare of laboratory animals and experimental procedures were approved by the responsible ethics committee of the UMCG (6946). In vivo sterol concentrations were determined as previously described [17].

\section{Cell culture}

HepG2 cells were grown in MEM supplemented with 10\% FCS, sodium pyruvate and non-essential amino acids and pen/strep as described [18]. Collection and differentiation of human primary myotubes have been described previously [19]. Growth and differentiation of human primary differentiated adipocytes have been described before [20], however, modifications have been applied to the original protocol. In short, human adipose tissue biopsies derived from deep neck surgery were incubated with collagenase to collect the stromal vascular fraction. Collected cells were grown to confluence before differentiation was initiated. Differentiation was initiated for 7 days via differentiation medium made up of biotin $(33 \mu \mathrm{M})$, pantothenate $(17 \mu \mathrm{M})$, insulin $(100 \mathrm{nM})$, dexamethasone $(100 \mathrm{nM})$, IBMX $(250 \mu \mathrm{M})$, rosiglitazone $(5 \mu \mathrm{M}), \mathrm{T} 3(2 \mathrm{nM})$, and transferrin $(10 \mu \mathrm{g} / \mathrm{ml})$. Cells were transferred to maintenance medium consisting of biotin $(33 \mu \mathrm{M})$, pantothenate $(17 \mu \mathrm{M})$, insulin $(100 \mathrm{nM})$, dexamethasone $(10 \mathrm{nM}), \mathrm{T} 3(10 \mathrm{nM})$ and transferrin $(10 \mu \mathrm{g} / \mathrm{ml})$ for 5 additional days.

\section{Cellular respiration}

Cells were plated and/or differentiated in XF96 cell culture microplates (Agilent Technologies, Santa Clara, CA, USA). After $24 \mathrm{~h}$ incubation with $12 \mu \mathrm{M}$ sitosterol or $1.2 \mu \mathrm{M}$ sitostanol or vehicle, oxygen consumption and mitochondrial function were measured using the Seahorse XF96 extracellular flux analyzer (Agilent Technologies, Santa Clara, CA, USA). Cells were incubated for $1 \mathrm{~h}$ at $37{ }^{\circ} \mathrm{C}$ in unbuffered $\mathrm{XF}$ assay medium. For HepG2, XF medium was supplemented with 5.5 or $25 \mathrm{mM}$ glucose (Sigma Aldrich, Saint 
Louis, MO, USA), 2 mM GlutaMax (Thermo Fisher Scientific, Waltham, MA, USA) and $1 \mathrm{mM}$ sodium pyruvate (Thermo Fisher Scientific, Waltham, MA, USA). For human primary cultured myotubes XF medium was supplemented with $5.5 \mathrm{mM}$ glucose, $4 \mathrm{mM}$ GlutaMax and $1 \mathrm{mM}$ sodium pyruvate. For cultured human primary adipocytes derived from WAT or BAT XF assay medium was supplemented with $25 \mathrm{mM}$ glucose, $2 \mathrm{mM}$ GlutaMax and $1 \mathrm{mM}$ sodium pyruvate. Basal oxygen consumption rate (OCR) was measured. Followed by injections (which can be seen in the trace) of $1 \mu \mathrm{M}$ oligomycin (inhibitor ATP-synthase/complex V of the electron transport chain), $1 \mu \mathrm{M}$ beta-adrenergic agonist norepinephrine (NE), $0.5 \mu \mathrm{M}$ mitochondrial uncoupler FCCP, $10 \mathrm{mM}$ pyruvate or $1 \mu \mathrm{M}$ rotenone + antimycin A (inhibitor of complex I and III of the electron transport chain). Oligomycin and NE were purchased from SigmaAldrich. In cultured human adipocytes, mitochondrial uncoupling was examined as mitochondrial respiration after the inhibition of ATP synthase with oligomycin (which was set to $100 \%$ ), thus reflecting mitochondrial uncoupling because of proton leak. In other cultured cells basal respiration was set to $100 \%$.

\section{Statistics}

For XF seahorse cellular respiration experiments, differences were analyzed using a two-way analysis of variance (ANOVA) in GraphPad Prism (GraphPad Software Inc., San Diego, CA, USA). Statistical significance was set at $p<0.05$.

\section{Results}

To verify the effects of plant sterols and stanols on wholebody metabolism, body weight development was determined in apoE KO mice and ABCG8 KO mice following a chow diet of 32 weeks. The ABCG8 KO background was chosen because of the manifestation of phytosterolemia [21]. The ABCG8 background increased sitosterol from $4.9 \pm 1.1 \mathrm{mg} /$ $\mathrm{dl}$ to $67.4 \pm 12.7 \mathrm{mg} / \mathrm{dl}$ and campesterol from $11.8 \pm 2.9 \mathrm{mg} /$ dl to $24.1 \pm 4.3 \mathrm{mg} / \mathrm{dl}(n=14-15) "$. As shown in Fig. 1, apoE $\times$ ABCG8 KO mice did not increase their body weight in a comparable manner as the apoE KO mice. We here speculate that the reduced body weight development could be explained by increased energy expenditure in organs containing high numbers of mitochondria. Thus to further translate this hypothesis to human tissues we next performed in vitro experiments on human adipocytes, skeletal muscle and liver cells.

In vitro, we examined the effects of long-term $(24 \mathrm{~h})$ incubation of sitosterol or sitostanol on cultured adipocytes derived from human BAT or WAT. In human adipocytes derived from BAT or WAT, neither sitosterol nor sitostanol was able to affect

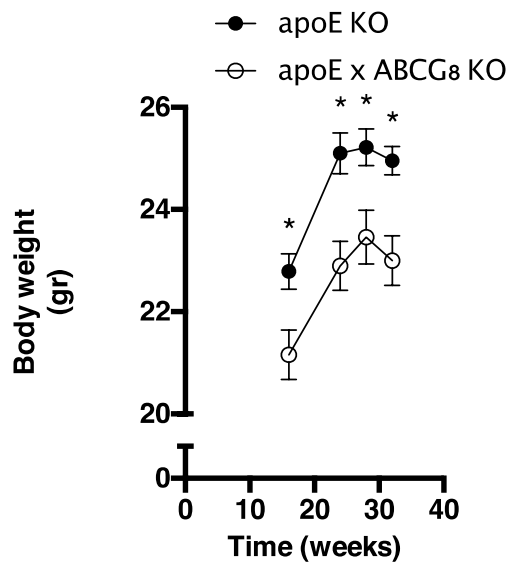

Fig. 1 High levels of plant sterol and stanol affect body weight in mice. ApoE KO or apoE $\times$ ABCG8 KO were fed a chow diet for 32 weeks. Data are expressed as mean $\pm \operatorname{SEM}(n=7) . * p<0.05$

basal oxygen consumption rate (OCR). Adipocytes derived from human BAT showed a clear NE-stimulated increase in OCR, a response that was absent in adipocytes derived from WAT, illustrating the characteristic uncoupling capacity of BAT. However, the addition of sitosterol or sitostanol did not enhance mitochondrial uncoupling capacity as measured by NE-stimulated cellular respiration in adipocytes derived from either human BAT or WAT (Fig. 2a, b).

Next, we assessed whether sitosterol or sitostanol can affect cellular respiration in cultured liver cells hepG2 in times of energy deficit, here mimicked by low glucose medium. When hepG 2 cells were incubated for $24 \mathrm{~h}$ with sitosterol or sitostanol, in contrast to our hypothesis, maximal respiration was significantly decreased when cells were incubated at low glucose concentrations (Fig. 3a, b). When hepG2 cells were tested in high glucose concentration this did not affect cellular respiration in the presence or absence of sitosterol or sitostanol.

Besides WAT, BAT, and liver, the metabolic syndrome is a major risk factor for the development of type 2 diabetes, in which glucose disposal is compromised the most in skeletal muscle [22]. Therefore, to complete our series of experiments, we examined whether skeletal muscle mitochondrial function was altered, also because human subjects with the metabolic syndrome benefitted from sitosterol or sitostanol-mediated TG reductions. However, our cellular respiration experiments in cultured human myotubes did not show changes following 24-h incubation with sitosterol or sitostanol (Fig. 4).

\section{Discussion}

In the current manuscript, first we demonstrate that mice with elevated plant sterol concentrations show diminished body weight gain. Consuming plant sterols and stanols is an 

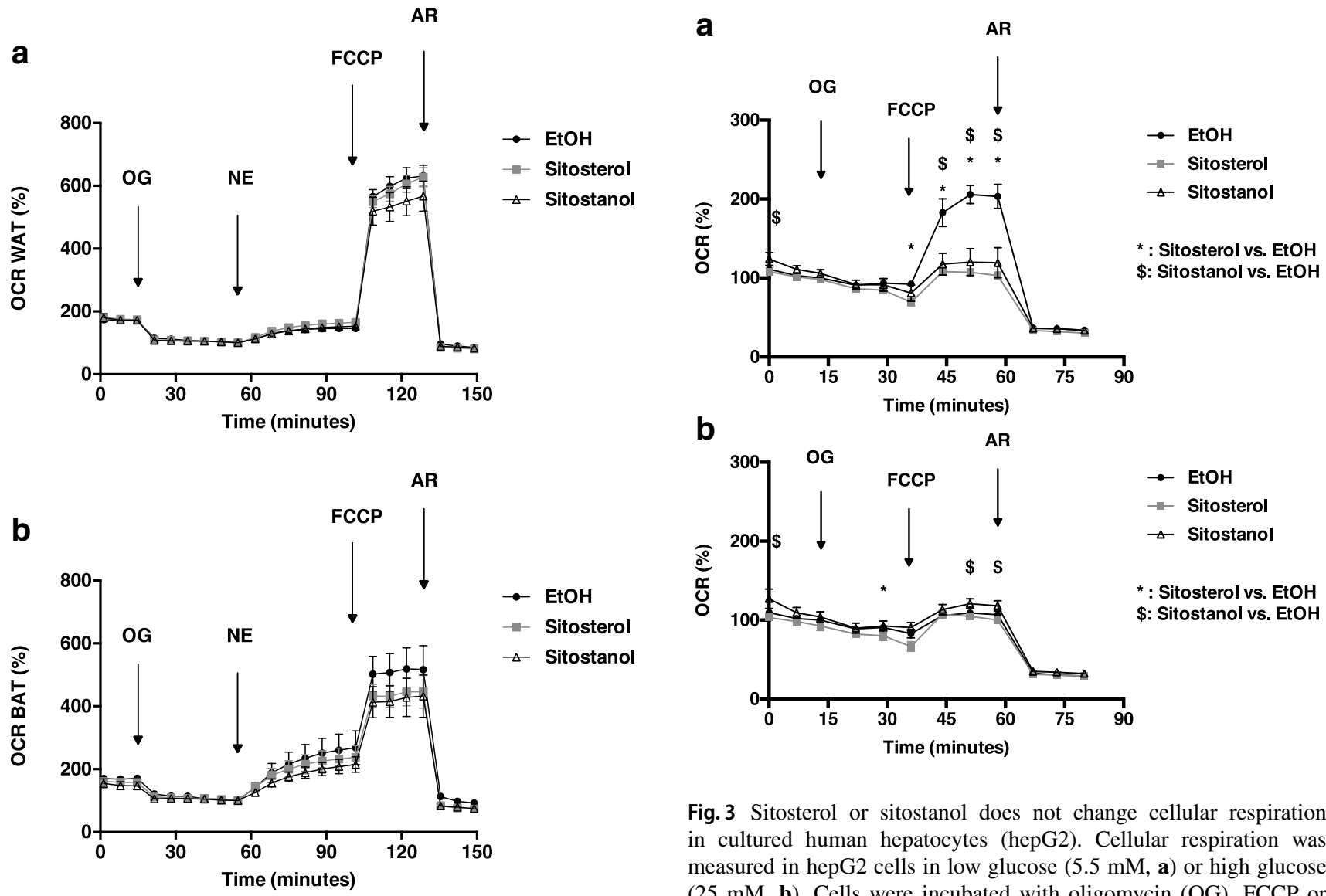

Fig. 3 Sitosterol or sitostanol does not change cellular respiration in cultured human hepatocytes (hepG2). Cellular respiration was measured in hepG2 cells in low glucose $(5.5 \mathrm{mM}$, a) or high glucose $(25 \mathrm{mM}, \mathbf{b})$. Cells were incubated with oligomycin (OG), FCCP or antimycin $\mathrm{A}+$ rotenone (AR). Data are expressed as mean $\pm \mathrm{SD}$

Fig. 2 Sitosterol or sitostanol does not alter cellular respiration in cultured human adipocytes. Cellular respiration was measured in cultured adipocytes derived from human WAT (a) or BAT (b). Adipocytes were incubated for $24 \mathrm{~h}$ with sitosterol, sitostanol or vehicle only (EtOH). Cells were exposed to oligomycin (OG), norepinephrine (NE), FCCP and antimycin A+rotenone (AR) at the indicated arrows. Data are expressed as mean $\pm \operatorname{SEM}(n=7$ for WAT, $n=4$ for BAT)

alternative approach to elevate serum concentrations while at the same time lowering serum TG. We hypothesized that elevated mitochondrial activity could link these effects to the elevated plant sterol concentrations. Therefore, we here examined the in vitro effects of sitosterol and sitostanol on mitochondrial function in BAT, WAT, liver, and muscle. Unfortunately, our hypothesis could not be confirmed in the utilized in vitro models for human BAT, WAT, liver or skeletal muscle.

Plant sterols and stanols could potentially affect energy metabolism through mitochondrial metabolism. Having elevated serum plant sterol concentrations, ABCG8 KO mice showed decreased body weight gain compared to control mice consuming the same chow diet (Fig. 1), which could be explained by a change in energy intake. Moreover, Schonewille et al. reported that mice fed a HFD-diet enriched with plant sterols or stanols consumed more calories but did not

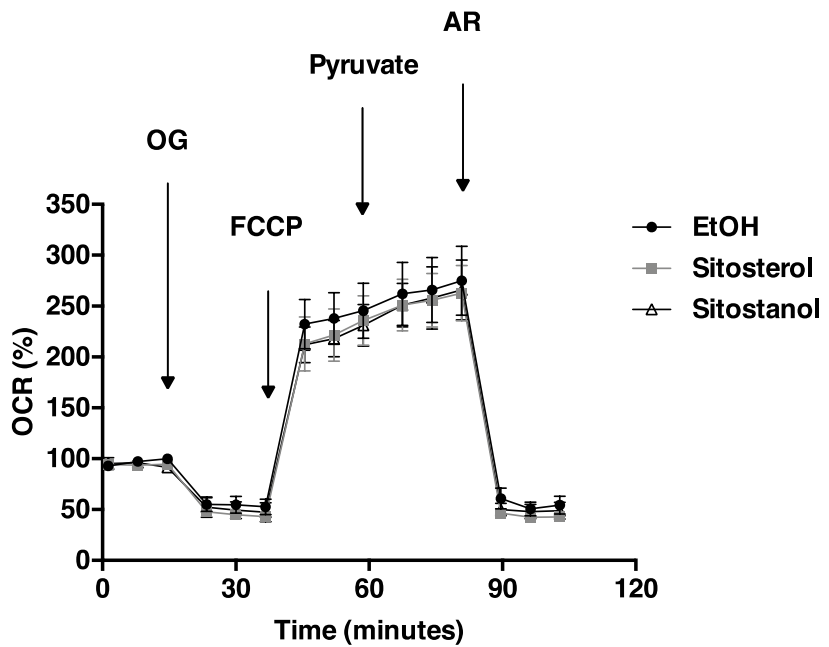

Fig. 4 Sitosterol or sitostanol does not alter cellular respiration in cultured human myotubes. Myotubes were exposed to oligomycin (OG), FCCP, pyruvate and antimycin A + rotenone (AR). Data are expressed as mean $\pm \operatorname{SEM}(n=3)$ 
gain more weight compared to control littermates [8]. We proposed that increased BAT activity could not only play a role in lowering TG concentrations but also be responsible for increased energy expenditure resulting in lower body weight gain. Therefore, to evaluate a potential role for BAT in plant sterols and stanols action, we used an in vitro model to examine human BAT activity, which shows similarities to BAT activity in vivo in humans [20,23]. Although, we did not observe a change in vitro BAT activity, this still would require in vivo experiments in humans to validate our in vitro results. So far, no other in-depth studies on mitochondrial function have been performed on plant sterols and stanols in various organs in parallel, and indeed the few experiments in mitochondria have not always yielded clear results because different cell systems have been used. For example, in isolated mitochondria from the brain, stigmasterol was unable to change ROS production [24]. On the other hand, betasitosterol enhanced mitochondrial membrane potential and mitochondrial ATP content in isolated mitochondria from hippocampal neuronal cells [25] and the ATP-stimulating effects of sitosterol have also been observed in H9c2 cardiomyocytes [26]. Not without surprise, high concentrations of stigmasterol can trigger apoptosis in hepG2 [27], which was also observed when using high concentrations of 7beta-hydroxysitosterol in human colon cancer cells [28]. However, in our experiments we have chosen physiologically relevant concentrations without toxic side effects. Various ways exist to measure mitochondrial function, which in the end could introduce variation when measuring mitochondrial function in vitro and/or in vivo. Therefore in the current setting it is of high value that various organs have been examined in parallel using similar experimental setups.

Plant sterols and stanols decrease TGs in mice, which is further associated with decreased secretion of large TG-rich VLDL-1 particles from the liver [8]. In vivo, plant sterols and stanols reach the liver via chylomicrons [29], because of the structural resemblance to cholesterol. In this situation, elevated concentration of plant sterols and stanols in the diet lowered local hepatic inflammation [30],however, experiments on mitochondrial function have not been performed. In contrast, long-term treatment of human subjects with intralipid (which contains plant sterols and stanols) resulted in liver damage [31,32]. Although it has not been proven that liver damage is causally linked to plant sterols, it is striking that after switching from intralipid to a plant sterol-poor fat emulsion in the parenteral nutrition regimen, liver function is restored $[33,34]$. The exact mechanism underlying potential harmful effects of plant sterols when supplied via parenteral routes is unknown, however, disturbed mitochondrial function has been mentioned. Further in-depth experiments on mitochondrial membrane fluidity following sitosterol and sitostanol could provide more information regarding how exactly sitosterol and sitostanol increase ATP content and mitochondrial membrane potential [25] that in the end stimulates whole-body metabolism. This effect on mitochondria is more or less in line with our findings presented here. These findings therefore could be interpreted as being harmful,however, thus far no negative side effects have been reported using plant sterols and/or plant stanols indicating that the human body can counter possible side effects.

To conclude, the TG-lowering potential of plant sterols and stanols is generally accepted. Based on our findings, we here conclude that in vitro mitochondrial function of human BAT, WAT, liver and skeletal muscle can be excluded as a target in the TG-lowering action accomplished by sitosterol or sitostanol. It is therefore most likely that the TG-lowering effects are linked to decreased hepatic VLDL production as proposed earlier.

Acknowledgements The project was funded by the Dutch Organization for Scientific Research (TOP Grant no. 91208006).

\section{Compliance with ethical standards}

Conflict of interest The authors declare that they have no conflict of interest.

Ethical statement Experiments were conducted in conformity with the law on the welfare of laboratory animals and experimental procedures were approved by the responsible ethics committee of the UMCG (6946).

Open Access This article is distributed under the terms of the Creative Commons Attribution 4.0 International License (http://creativeco mmons.org/licenses/by/4.0/), which permits unrestricted use, distribution, and reproduction in any medium, provided you give appropriate credit to the original author(s) and the source, provide a link to the Creative Commons license, and indicate if changes were made.

\section{References}

1. Gylling H, Plat J, Turley S, Ginsberg HN, Ellegard L, Jessup W, Jones PJ, Lutjohann D, Maerz W, Masana L, Silbernagel G, Staels B, Boren J, Catapano AL, De Backer G, Deanfield J, Descamps OS, Kovanen PT, Riccardi G, Tokgozoglu L, Chapman MJ (2014) Plant sterols and plant stanols in the management of dyslipidaemia and prevention of cardiovascular disease. Atherosclerosis 232(2):346-360. https://doi.org/10.1016/j.atheroscle rosis.2013.11.043

2. Plat J, Brufau G, Dallinga-Thie GM, Dasselaar M, Mensink RP (2009) A plant stanol yogurt drink alone or combined with a lowdose statin lowers serum triacylglycerol and non-HDL cholesterol in metabolic syndrome patients. J Nutr 139(6):1143-1149. https ://doi.org/10.3945/jn.108.103481

3. Hegele RA, Ginsberg HN, Chapman MJ, Nordestgaard BG, Kuivenhoven JA, Averna M, Boren J, Bruckert E, Catapano AL, Descamps OS, Hovingh GK, Humphries SE, Kovanen PT, Masana L, Pajukanta P, Parhofer KG, Raal FJ, Ray KK, Santos RD, Stalenhoef AF, Stroes E, Taskinen MR, Tybjaerg-Hansen A, 
Watts GF, Wiklund O (2014) The polygenic nature of hypertriglyceridaemia: implications for definition, diagnosis, and management. Lancet Diabetes Endocrinol 2(8):655-666. https://doi. org/10.1016/S2213-8587(13)70191-8

4. Bansal S, Buring JE, Rifai N, Mora S, Sacks FM, Ridker PM (2007) Fasting compared with nonfasting triglycerides and risk of cardiovascular events in women. JAMA 298(3):309-316. https ://doi.org/10.1001/jama.298.3.309

5. Nordestgaard BG, Benn M, Schnohr P, Tybjaerg-Hansen A (2007) Nonfasting triglycerides and risk of myocardial infarction, ischemic heart disease, and death in men and women. JAMA 298(3):299-308. https://doi.org/10.1001/jama.298.3.299

6. Demonty I, Ras RT, van der Knaap HC, Meijer L, Zock PL, Geleijnse JM, Trautwein EA (2013) The effect of plant sterols on serum triglyceride concentrations is dependent on baseline concentrations: a pooled analysis of 12 randomised controlled trials. Eur J Nutr 52(1):153-160. https://doi.org/10.1007/s0039 4-011-0297-x

7. Theuwissen E, Plat J, van der Kallen CJ, van Greevenbroek MM, Mensink RP (2009) Plant stanol supplementation decreases serum triacylglycerols in subjects with overt hypertriglyceridemia. Lipids 44(12):1131-1140. https://doi.org/10.1007/s1174 5-009-3367-6

8. Schonewille M, Brufau G, Shiri-Sverdlov R, Groen AK, Plat J (2014) Serum TG-lowering properties of plant sterols and stanols are associated with decreased hepatic VLDL secretion. $\mathrm{J}$ Lipid Res 55(12):2554-2561. https://doi.org/10.1194/jlr.M0524 07

9. Plat J, Mensink RP (2009) Plant stanol esters lower serum triacylglycerol concentrations via a reduced hepatic VLDL-1 production. Lipids 44(12):1149-1153. https://doi.org/10.1007/ s11745-009-3361-z

10. Baumgartner S, Mensink RP, Plat J (2016) Effects of a plant sterol or stanol enriched mixed meal on postprandial lipid metabolism in healthy subjects. PLoS ONE 11(9):e0160396. https://doi.org/10.1371/journal.pone.0160396

11. Cannon B, Nedergaard J (2004) Brown adipose tissue: function and physiological significance. Physiol Rev 84(1):277-359. https://doi.org/10.1152/physrev.00015.2003

12. Cypess AM, Kahn CR (2010) Brown fat as a therapy for obesity and diabetes. Curr Opin Endocrinol Diabetes Obes 17(2):143149. https://doi.org/10.1097/MED.0b013e328337a81f

13. Schrauwen P, van Marken Lichtenbelt WD (2016) Combatting type 2 diabetes by turning up the heat. Diabetologia 59(11):2269-2279. https://doi.org/10.1007/s00125-016-4068-3

14. Ouellet V, Labbe SM, Blondin DP, Phoenix S, Guerin B, Haman F, Turcotte EE, Richard D, Carpentier AC (2012) Brown adipose tissue oxidative metabolism contributes to energy expenditure during acute cold exposure in humans. J Clin Investig 122(2):545-552. https://doi.org/10.1172/JCI60433

15. Bartelt A, Bruns OT, Reimer R, Hohenberg H, Ittrich H, Peldschus K, Kaul MG, Tromsdorf UI, Weller H, Waurisch C, Eychmuller A, Gordts PL, Rinninger F, Bruegelmann K, Freund B, Nielsen P, Merkel M, Heeren J (2011) Brown adipose tissue activity controls triglyceride clearance. Nat Med 17(2):200205. https://doi.org/10.1038/nm.2297

16. Geerling JJ, Boon MR, van der Zon GC, van den Berg SA, van den Hoek AM, Lombes M, Princen HM, Havekes LM, Rensen PC, Guigas B (2014) Metformin lowers plasma triglycerides by promoting VLDL-triglyceride clearance by brown adipose tissue in mice. Diabetes 63(3):880-891. https://doi.org/10.2337/ db13-0194

17. Mackay DS, Jones PJ, Myrie SB, Plat J, Lutjohann D (2014) Methodological considerations for the harmonization of noncholesterol sterol bio-analysis. J Chromatogr B Anal Technol
Biomed Life Sci 957:116-122. https://doi.org/10.1016/j.jchro mb.2014.02.052

18. van der Krieken SE, Popeijus HE, Mensink RP, Plat J (2017) Link between ER-stress, PPAR-alpha activation, and BET inhibition in relation to apolipoprotein A-I transcription in HepG2 cells. J Cell Biochem 118(8):2161-2167. https://doi. org/10.1002/jcb. 25858

19. Sparks LM, Bosma M, Brouwers B, van de Weijer T, Bilet L, Schaart G, Moonen-Kornips E, Eichmann TO, Lass A, Hesselink MKC, Schrauwen P (2014) Reduced incorporation of fatty acids into triacylglycerol in myotubes from obese individuals with type 2 diabetes. Diabetes 63(5):1583-1593. https://doi. org/10.2337/db13-1123

20. Broeders EP, Nascimento EB, Havekes B, Brans B, Roumans KH, Tailleux A, Schaart G, Kouach M, Charton J, Deprez B, Bouvy ND, Mottaghy F, Staels B, van Marken Lichtenbelt WD, Schrauwen P (2015) The bile acid chenodeoxycholic acid increases human brown adipose tissue activity. Cell Metab 22(3):418-426. https://doi.org/10.1016/j.cmet.2015.07.002

21. Klett EL, Lu K, Kosters A, Vink E, Lee MH, Altenburg M, Shefer S, Batta AK, Yu H, Chen J, Klein R, Looije N, OudeElferink R, Groen AK, Maeda N, Salen G, Patel SB (2004) A mouse model of sitosterolemia: absence of Abcg8/sterolin-2 results in failure to secrete biliary cholesterol. BMC Med 2:5. https://doi.org/10.1186/1741-7015-2-5

22. DeFronzo RA (1988) Lilly lecture 1987. The triumvirate: betacell, muscle, liver. A collusion responsible for NIDDM. Diabetes 37(6):667-687

23. Nascimento EBM, Sparks LM, Divoux A, van Gisbergen MW, Broeders EPM, Jorgensen JA, Schaart G, Bouvy ND, van Marken Lichtenbelt WD, Schrauwen P (2018) Genetic markers of brown adipose tissue identity and in vitro brown adipose tissue activity in humans. Obesity 26(1):135-140. https://doi. org/10.1002/oby.22062

24. Panov A, Kubalik N, Brooks BR, Shaw CA (2010) In vitro effects of cholesterol beta-D-glucoside, cholesterol and cycad phytosterol glucosides on respiration and reactive oxygen species generation in brain mitochondria. J Membr Biol 237(23):71-77. https://doi.org/10.1007/s00232-010-9307-9

25. Shi C, Wu F, Xu J (2013) Incorporation of beta-sitosterol into mitochondrial membrane enhances mitochondrial function by promoting inner mitochondrial membrane fluidity. J Bioenerg Biomembr 45(3):301-305. https://doi.org/10.1007/s1086 3-012-9495-3

26. Wong HS, Chen N, Leong PK, Ko KM (2014) beta-Sitosterol enhances cellular glutathione redox cycling by reactive oxygen species generated from mitochondrial respiration: protection against oxidant injury in $\mathrm{H} 9 \mathrm{c} 2$ cells and rat hearts. Phytother Res 28(7):999-1006. https://doi.org/10.1002/ptr.5087

27. Kim YS, Li XF, Kang KH, Ryu B, Kim SK (2014) Stigmasterol isolated from marine microalgae Navicula incerta induces apoptosis in human hepatoma HepG2 cells. BMB Rep 47(8):433-438

28. Roussi S, Gosse F, Aoude-Werner D, Zhang X, Marchioni E, Geoffroy P, Miesch M, Raul F (2007) Mitochondrial perturbation, oxidative stress and lysosomal destabilization are involved in 7beta-hydroxysitosterol and 7beta-hydroxycholesterol triggered apoptosis in human colon cancer cells. Apoptosis 12(1):87-96. https://doi.org/10.1007/s10495-006-0485-y

29. De Smet E, Mensink RP, Plat J (2012) Effects of plant sterols and stanols on intestinal cholesterol metabolism: suggested mechanisms from past to present. Mol Nutr Food Res 56(7):1058-1072. https://doi.org/10.1002/mnfr.201100722

30. Plat J, Hendrikx T, Bieghs V, Jeurissen ML, Walenbergh SM, van Gorp PJ, De Smet E, Konings M, Vreugdenhil AC, Guichot YD, Rensen SS, Buurman WA, Greve JW, Lutjohann D, Mensink RP, Shiri-Sverdlov R (2014) Protective role of plant sterol 
and stanol esters in liver inflammation: insights from mice and humans. PLoS O ne 9(10):e110758. https://doi.org/10.1371/ journal.pone.0110758

31. Clayton PT, Bowron A, Mills KA, Massoud A, Casteels M, Milla PJ (1993) Phytosterolemia in children with parenteral nutrition-associated cholestatic liver disease. Gastroenterology 105(6):1806-1813

32. Clayton PT, Whitfield P, Iyer K (1998) The role of phytosterols in the pathogenesis of liver complications of pediatric parenteral nutrition. Nutrition 14(1):158-164

33. Gura KM, Duggan CP, Collier SB, Jennings RW, Folkman J, Bistrian BR, Puder M (2006) Reversal of parenteral nutrition-associated liver disease in two infants with short bowel syndrome using parenteral fish oil: implications for future management. Pediatrics 118(1):e197-e201. https://doi.org/10.1542/ peds.2005-2662

34. Gura KM, Lee S, Valim C, Zhou J, Kim S, Modi BP, Arsenault DA, Strijbosch RA, Lopes S, Duggan C, Puder M (2008) Safety and efficacy of a fish-oil-based fat emulsion in the treatment of parenteral nutrition-associated liver disease. Pediatrics 121(3):e678-e686. https://doi.org/10.1542/peds.2007-2248 